\title{
Crop regulation in guava cv. Sardar as influenced by chemicals and cultural practices under semi arid conditions of Rajasthan
}

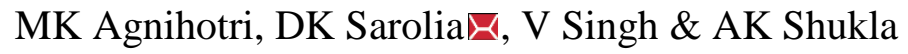 \\ Department of Horticulture, Rajasthan College of Agriculture, Udaipur \\ Corresponding author: Sarolia DK, E-mail: deephorti@gmail.com
}

Copyright (C2016 Agnihotri et al, This is an open access article published under the terms of the Creative Commons Attribution License, which permits unrestricted use, distribution, and reproduction in any medium, provided the original work is properly cited.

Preferred citation for this article: Agnihotri MK, Sarolia DK, Singh V \& Shukla AK. 2016. Crop regulation in guava cv. Sardar as influenced by chemicals and cultural practices under semi arid conditions of Rajasthan. Journal of Agriculture and Ecology, 1: 85-90 http://doi.org/10.53911/JAE.2016.1110.

\begin{abstract}
A field experiment was conducted at Instrumental Farm, Department of Horticulture, Rajasthan College of Agriculture, Udaipur. The experiment consisted of 8 treatments comprising chemicals (Urea @ 10\% and 15\% foliar spray, NAA @ 1000 ppm) and cultural practices (pruning at $75 \%$ and $50 \%$ intensity, bending of shoots, withholding of irrigation water) were applied during the course of investigation. These treatments were evaluated under randomized block design with 4 replications by adopting uniform cultural schedule during the experimentation. The results revealed that all treatments had significant increase in vegetative growth characteristics (number of newly emerged shoots, per cent increase in shoot growth after 30 days interval, canopy volume, PAR above and below canopy and leaf area index) physico-chemical characteristics(Fruit weight, pulp thickness, pulp: seed ratio, TSS, acidity, ascorbic acid content, total sugars and reducing sugar) and yield characteristics( per cent fruit retention, number of fruits per plant, yield per tree and yield per hectare) over the Ambe bahar and control. Among the treatments foliar spray of NAA @ 1000 ppm in the month of April $\left(\mathrm{T}_{7}\right)$ significantly increase the canopy volume $\left(371.55 \mathrm{~m}^{3}\right)$, fruit weight $(152.60 \mathrm{~g})$, pulp thickness $(1.13 \mathrm{~cm})$, pulp seed ratio (58:90), TSS (13.80\%), ascorbic acid (193.75 mg/100 gm pulp), total sugars (7.29\%) and reducing sugar $(4.21 \%)$ followed by application of single foliar spray of 15 per cent urea at 50 per cent bloom stage $\left(\mathrm{T}_{2}\right)$. Number of fruit per plant $(389.50)$, yield per tree $(56.38 \mathrm{~kg})$ estimated fruit yield (156.39 $\mathrm{q} \mathrm{ha}^{-1}$ ) with higher net return (Rs.109394.88 $\mathrm{ha}^{-1}$ ) and B: C ratio (2.81:1) were recorded maximum in $\mathrm{T} 2$.
\end{abstract}

Key Words: Crop regulation, NAA, urea, pruning 


\section{Introduction}

Guava (Psidium guajava L.) is one of the most exquisite and valuable fruits of the tropics and belongs to the family 'Myrtaceae'. It has been under cultivation in India since early $17^{\text {th }}$ century. It is the fifth important fruit crop after mango, banana, papaya and citrus with covering an area of 268.2 thousand hectares with total production of 3667.9 thousand tonnes and productivity of $13.70 \mathrm{t} / \mathrm{ha}$ in India (Anonymous 2015). In Rajasthan, it is the third most important fruit crop after citrus and mango occupies an area of 2470 hectare with an annual production of 24620 tonnes (Anonymous 2015). In Rajasthan major guava growing districts are Sawaimadhopur, Kota, Bundi, Ajmer, Udaipur and Chittorgarh. Guava dose equally well under tropics and sub tropical climatic conditions. Under tropical climate due to availability of sufficient heat and moisture, produce fruit almost continuously. However, in sub tropical climate there are three distinct periods of growth and fruiting. There are Ambe bahar - February to March flowering and fruit ripens in July - August, Mrig bahar - June to July flowering and fruit ripens October to December and Hast bahar - October to November flowering and fruit ripens in February to April (Shukla et al. 2008). Further, flowering and fruiting through out the year may cause poor fruit quality and yield, particularly during rainy season crop (Ambe bahar); maximum fruits get infected with fruit fly. Therefore, it is essential to take on commercial crop instead of all. Mrig bahar is considered as best fruiting season because of lower infestation of fruit fly and good quality fruits. In order to avoid heavy crop load during rainy season, chemicals and cultural means are important tools for crop regulation to get quantum and quality yield (Singh 2001). During last 3-4 decades sufficient research work in guava has been done on various aspects like crop improvement, use of organic and inorganic fertilizers etc. however, impact of plant growth regulators, chemicals and other cultural practices in regulation of flowering and fruiting of guava has not been fully exploited in context of Southern Rajasthan agro climatic conditions. Keeping in view the present experiment was carried out to study the response of chemicals and cultural practices on growth, yield and quality of guava cv. 'Sardar' in Mrig bahar as compare to Ambe bahar and find out appropriate treatment for crop regulation.

\section{Materials \& Methods}

Experiment was conducted at Instructional Farm of Department of Horticulture, Rajasthan College of Agriculture, Udaipur. The experiment consisted of 8 treatments comprising water spray $\left(\mathrm{T}_{0}\right)$, urea @ 10\% foliar spray $\left(\mathrm{T}_{1}\right)$, urea foliar spray 15\% $\left(\mathrm{T}_{2}\right)$, NAA foliar spray 1000 ppm $\left(\mathrm{T}_{3}\right)$, pruning at $75 \%$ intensity $\left(\mathrm{T}_{4}\right)$, pruning at $50 \%$ intensity $\left(\mathrm{T}_{5}\right)$, bending of shoots $\left(\mathrm{T}_{6}\right)$, withholding of irrigation water $\left(\mathrm{T}_{7}\right)$ were applied during the course of investigation. These treatments were evaluated under randomized block design with 4 replications by adopting uniform cultural schedule during the experimentation. All quality parameters of fruits were analyzed as per standards methods given in (AOAC 1990) and statistical data interpreted accordance to Snedecor and Cochran 1967. 


\section{Results and Discussion}

Growth parameters: Vegetative growth parameters of treated plants exhibited significantly higher number of newly emerged shoots, per cent increase in shoot growth after 30 days interval and canopy volume over control (Table1). Treatment $\mathrm{T}_{3}$ (pruning with $75 \%$ intensity at $50 \%$ bloom stage in the month of April) showed significantly superior with respect to number of newly emerged shoots, per cent increase in shoot growth after 60 days of pruning, whereas, $\mathrm{T}_{4}$ (heading back of terminal branches with $50 \%$ intensity at $50 \%$ bloom stage in the month of April) found superior with per cent increase in shoot growth after 30 and 90 days. Treatment $\mathrm{T}_{7}$ (foliar spray of NAA @ 1000 ppm in the month of April) showed significant superior with respect to canopy volume over control and Ambe Bahar. Further, $\mathrm{T}_{1}$ (foliar spray of $10 \%$ urea at the time of 50 per cent bloom stage. Second foliar spray of same dose after 10 days of fruit spray) and $\mathrm{T}_{7}$ was statistically at par. It might be due to well response of vegetative growth to pruning and narrow $\mathrm{C}$ : $\mathrm{N}$ ratio of plant that induce vegetative flush in tree (Anez 1998) that resulted in vigorous growth of plant (Jadhav et al. 1998). The increase in plant canopy, number of shoots and percent increase in growth may be due to positive response of treatment. Which reduce the crop load of the Ambe bahar and whole energy was diverted towards the vegetative growth of plant. Highest canopy volume with foliar spray of NAA @ 1000 ppm may due to its immediate absorption which increased the endogenous auxin level that resulted in cell elongation and enhanced vegetative growth (Singh et al. 1992)

Table1. Response of chemicals and cultural practices on vegetative growth characteristics

\begin{tabular}{|c|c|c|c|c|c|}
\hline \multirow{2}{*}{ Treatments } & \multirow{2}{*}{$\begin{array}{c}\text { No. of } \\
\text { newly } \\
\text { emerged } \\
\text { shoots }\end{array}$} & \multicolumn{3}{|c|}{ Percent increase in shoot growth } & \multirow{2}{*}{$\begin{array}{c}\text { Canopy } \\
\text { volume }\left(\mathrm{m}^{3}\right) \\
182.64(\text { Ambe } \\
\text { bahar })\end{array}$} \\
\hline & & 30 days & 60 days & 90 days & \\
\hline $\mathrm{T}_{0}$ & 2.55 & $10.60(18.96)$ & $4.57(12.07)$ & $1.30(6.67)$ & 193.10 \\
\hline $\mathrm{T}_{1}$ & 3.80 & $10.62(19.01)$ & $7.08(15.33)$ & $2.68(9.44)$ & 348.68 \\
\hline $\mathrm{T}_{2}$ & 3.50 & $10.62(19.01)$ & $7.10(15.45)$ & $2.16(8.47)$ & 349.30 \\
\hline $\mathrm{T}_{3}$ & 4.60 & $13.31(21.36)$ & $8.30(16.62)$ & $3.28(10.43)$ & 197.83 \\
\hline $\mathrm{T}_{4}$ & 4.05 & $13.91(21.85)$ & $7.90(16.30)$ & $3.87(11.36)$ & 294.20 \\
\hline $\mathrm{T}_{5}$ & 3.00 & $11.53(19.81)$ & $6.89(15.19)$ & $2.14(8.42)$ & 238.90 \\
\hline $\mathrm{T}_{6}$ & 3.02 & $7.70(16.10)$ & $6.73(14.99)$ & $1.10(5.91)$ & 295.78 \\
\hline $\mathrm{T}_{7}$ & 3.35 & $11.70(20.02)$ & $7.13(15.47)$ & $2.94(9.62)$ & 371.55 \\
\hline $\mathrm{SEm} \pm$ & 0.33 & 0.43 & 0.35 & 0.39 & 11.90 \\
\hline $\mathrm{CD}$ at $5 \%$ & 0.98 & 1.27 & 1.05 & 1.15 & 34.99 \\
\hline
\end{tabular}

Yield attributes: Foliar application of NAA @ $1000 \mathrm{ppm}$ in the month of April $\left(\mathrm{T}_{7}\right)$ was significantly superior in terms of yield attributes over rest of treatments. Maximum fruit weight was recorded in $\mathrm{T}_{7}(152.60 \mathrm{~g})$ as compare to control $(98.25 \mathrm{~g})$. Further, pulp thickness $(1.13 \mathrm{~cm})$ and pulp: seed ratio (58.90) was highest in treatment $\mathrm{T}_{7}$ (Table 2). It might be due to adverse influence of foliar spray of 1000 ppm NAA on guava which cause burning and defoliation in rainy season. High vegetative growth due to residual effect of NAA on plants that resulted in high leaf to fruit ratio and high fruit weight, fruit volume, pulp thickness, pulp weight and pulp: 
seed ratio. In the literature regarding the influence of chemical treatments on fruit weight, fruit volume and pulp: seed ratio indirectly supported by the findings of Dubey et al (2002). Who observed that highest deblossoming of guava during rainy season and the highest yield and fruiting quality during the winter season with spray of 250 ppm NAA (Gaur 1996; Singh et al. 1992). Further, per cent fruit retention (60.00), number of fruits per plant (389.50), yield per plant $\left(56.38 \mathrm{~kg}\right.$ ) and estimated yield per hectare was superior in treatment $\mathrm{T}_{2}$ (Single foliar spray of $15 \%$ urea at $50 \%$ bloom stage) over rest of the treatments. Whereas highest fruit retention $\left(67.85 \%\right.$ ) in $\mathrm{T}_{3}$ (pruning at $75 \%$ intensity at $50 \%$ bloom stage in the month of April) while, all the characters had least value under $\mathrm{T}_{0}$ (control). On comparison of $\mathrm{T}_{2}$ (Mrig Bahar) with Ambe Bahar, $\mathrm{T}_{2}$ show significantly higher number of fruits, per cent fruit set, per cent fruit retention, number of fruits per plant, yield per plant and estimated yield per hectare. It might be due to owing to the improved nutritional status of plant. Due to foliar spray of urea at 15 per cent, tree tends to produce more flowers and that can be supported by photosynthesis and remobilization (Rajput et al. 1986). It might also be due to residual effect of higher concentration of urea on flowers abscission in rainy season and further increase in higher number of fruits per plant (Singh et al 2002). Increase in yield also may be due to higher fruit weight, more number of fruit per plant because of better leaf nutrient status in the leaves, which directly or indirectly helps in improve photosynthesis and translocation from source to sink. On economic ground, single spray of 15 per cent urea at 50 per cent bloom stage $\left(\mathrm{T}_{2}\right)$ significantly increased the net return (Rs. 109394.88) and $\mathrm{B}$ : $\mathrm{C}$ ratio (2.81: 1) over the rest of the treatments and least under control (Rs. 50170 and 1.34: 1 , respectively (Table 2).

Table2. Response of chemicals and cultural practices on yield attributes, yield and economics

\begin{tabular}{lccccccccc}
\hline Treatment & $\begin{array}{c}\text { Fruit } \\
\text { weight } \\
(\mathrm{g})\end{array}$ & $\begin{array}{c}\text { Pulp } \\
\text { thickness } \\
(\mathrm{cm})\end{array}$ & $\begin{array}{c}\text { Pulp:seed } \\
\text { ratio }\end{array}$ & $\begin{array}{c}\text { Per cent } \\
\text { fruit } \\
\text { retention }\end{array}$ & $\begin{array}{c}\text { No. of } \\
\text { fruits } \\
\text { per } \\
\text { plant }\end{array}$ & $\begin{array}{c}\text { Yield } \\
\text { per } \\
\text { tree } \\
(\mathrm{kg})\end{array}$ & $\begin{array}{c}\text { Yield } \\
\left(\mathrm{q} \text { ha }^{-1}\right)\end{array}$ & $\begin{array}{c}\text { Net } \\
\text { returns } \\
\left(\text { Rs. ha }^{-1}\right)\end{array}$ & $\begin{array}{c}\text { B:C } \\
\text { ratio }\end{array}$ \\
\hline $\begin{array}{l}\text { Ambe } \\
\text { bahar }\end{array}$ & 101.25 & 0.55 & 33.27 & $\begin{array}{c}45.74 \\
(42.53)\end{array}$ & 212.5 & 27.5 & 75.06 & - & - \\
$\mathrm{T}_{0}$ & 98.25 & 0.53 & 35.17 & $\begin{array}{c}49.30 \\
(44.61)\end{array}$ & 165.00 & 16.63 & 46.09 & 50170.00 & 1.34 \\
$\mathrm{~T}_{1}$ & 134.08 & 0.90 & 43.97 & $\begin{array}{c}62.30 \\
(52.14)\end{array}$ & 380.50 & 50.00 & 139.00 & 101332.7 & 2.49 \\
$\mathrm{~T}_{2}$ & 143.85 & 0.95 & 55.06 & $\begin{array}{c}58.70 \\
(50.01)\end{array}$ & 389.50 & 56.38 & 156.73 & 109394.8 & 2.81 \\
$\mathrm{~T}_{3}$ & 141.53 & 0.88 & 42.97 & $\begin{array}{c}69.60 \\
(56.57)\end{array}$ & 383.25 & 40.25 & 111.89 & 63520.00 & 1.65 \\
$\mathrm{~T}_{4}$ & 131.33 & 0.80 & 51.46 & $\begin{array}{c}67.85 \\
(55.42)\end{array}$ & 313.50 & 42.50 & 118.15 & 80569.00 & 2.10 \\
$\mathrm{~T}_{5}$ & 98.03 & 0.85 & 40.46 & $\begin{array}{c}59.90 \\
(50.70)\end{array}$ & 360.50 & 36.88 & 102.52 & 98842.00 & 2.52 \\
$\mathrm{~T}_{6}$ & 101.13 & 0.95 & 41.91 & $\begin{array}{c}51.64 \\
(45.90)\end{array}$ & 235.62 & 34.08 & 94.72 & 68101.00 & 1.83 \\
$\mathrm{~T}_{7}$ & 152.60 & 1.13 & 58.90 & $\begin{array}{c}59.86 \\
(50.67)\end{array}$ & 351.75 & 54.38 & 151.16 & 95119 & 1.45 \\
\hline
\end{tabular}


Journal of Agriculture and Ecology, 2016, Vol.1, 85-90

http://saaer.org.in

SAAER

\begin{tabular}{llllllllll}
\hline SEm \pm & 2.24 & 0.05 & 1.93 & 2.06 & 7.54 & 1.60 & 4.21 & 593.68 & 0.132 \\
$\mathrm{CD}$ at $5 \%$ & 7.17 & 0.16 & 5.69 & 6.06 & 22.20 & 4.73 & 12.39 & 1781.12 & 0.398 \\
\hline
\end{tabular}

Biochemical characteristics of fruits: Quality analysis of foliar spray of NAA @ 1000 ppm in the month of April exhibited maximum value of TSS (13.80\%), ascorbic acid (193.75 mg/100 g pulp), total sugars and reducing sugars (7.29\% and $4.21 \%$ respectively). The maximum TSS, sugars and ascorbic acid might be probably due to high leaf to fruit ratio because of restricted number of fruits harvested and high photosynthesis activity. The results are cognizance with the findings of Dubey et al. (2002), Singh et al. (1996) and Gaur (1996). Acidity of guava shows decreasing trend with the rising concentration of NAA (Dubey et al. 2002 and Singh et al. 1992) (Table 3).

Table 3. Response of chemicals and cultural practices on biochemical characteristics of fruits

\begin{tabular}{lccccc}
\hline Treatment & $\begin{array}{c}\text { TSS } \\
(\%)\end{array}$ & Acidity $(\%)$ & $\begin{array}{c}\text { Ascorbic acid } \\
\text { content }(\mathrm{mg} / \\
100 \mathrm{~g} \text { pulp) }\end{array}$ & $\begin{array}{c}\text { Total } \\
\text { sugars } \\
(\%)\end{array}$ & $\begin{array}{c}\text { Reducing } \\
\text { sugar } \\
(\%)\end{array}$ \\
\hline Ambe bahar & 10.40 & 1.05 & 132.50 & 5.92 & 3.40 \\
$\mathrm{~T}_{0}$ & 10.60 & 1.01 & 134.25 & 6.04 & 3.44 \\
$\mathrm{~T}_{1}$ & 12.50 & 0.77 & 175.63 & 7.27 & 3.83 \\
$\mathrm{~T}_{2}$ & 13.20 & 0.80 & 177.50 & 7.02 & 4.08 \\
$\mathrm{~T}_{3}$ & 13.00 & 0.75 & 170.63 & 7.05 & 3.95 \\
$\mathrm{~T}_{4}$ & 13.30 & 0.77 & 178.13 & 6.81 & 4.01 \\
$\mathrm{~T}_{5}$ & 12.70 & 0.85 & 176.25 & 6.38 & 3.92 \\
$\mathrm{~T}_{6}$ & 12.70 & 0.84 & 171.88 & 6.49 & 3.90 \\
$\mathrm{~T}_{7}$ & 13.80 & 0.82 & 193.75 & 7.29 & 4.21 \\
\hline $\mathrm{SEm} \pm$ & 0.40 & 0.03 & 6.06 & 0.23 & 0.10 \\
$\mathrm{CD}$ at $5 \%$ & 1.19 & 0.11 & 17.82 & 0.67 & 0.29 \\
\hline
\end{tabular}

\section{References}

AOAC. 1990. In: Official Methods of Analysis. Association of Official Agricultural Chemists. Benjamin Franklin Station, Washington, DC.

Anez QME. 1998. Effect of pruning on guava (Psidium guajava L.) clones. Revista Unellez de Ciencia Tecnologia Produccion Agricola, 16: 107-118.

Anonymous. 2015. Indian Horticulture Database, NHB, Gurgaon. 27 p.

Dubey AK, Singh DB \& Dubey N. 2002. Crop regulation in guava (Psidium guajava L.) cv. 'Allahabad Safeda'. Progressive Horticulture, 34:200-203.

Gaur G S. 1996. Studies on crop regulation of guava. Recent Horticulture, 3: 21-23.

Jadhao BJ, Damke MM \& Wagh AP. 1998. Studies on effect of time and severity of pruning on growth and yield of guava (Psidium guajava L.) cv. 'Sardar'. Journal of Soils and Crops, 8:139-141. 
Journal of Agriculture and Ecology, 2016, Vol.1, 85-90

http://saaer.org.in

Rajput CBS, Singh G \& Mishra JS. 1986. Crop regulation in guava by urea sprays. Indian Journal of Horticulture, 43:141-143.

Shukla AK, Kaushik RA, Pandey D \& Sarolia DK. 2008. In: Guava. Published by Maharana Pratap University of Agriculture and technology, Udaipur, pp: 7.

Singh G, Pandey D, Rajan S \& Singh AK. 1996. Crop regulation in guava through different crop regulating treatments. Fruit Paris, 51: 241-246.

Singh G, Singh AK \& Rajan S. 2001. Influence of pruning date on fruit yield of guava (Psidium guajava L.) under subtropics. Journal of Applied Horticulture, 3:37-40.

Singh G, Singh AK, Rajan S \& Bhriguvanshi S R. 2002. Strategy for crop regulation in guava (Psidium guajava L.) through foliar urea sprays and its effect on different $\mathrm{N}$ - form in leaves. Journal of Applied Horticulture, 4: 93-98.

Singh R, Singh SN, Gupta MR \& Dhaliwal G S. 1992. Studies of winter cropping in guava cv. 'Allahabad Safeda'. Indian Journal of Horticulture, 49: 127-133.

Snedecor GW \& Cochran W G. 1967. In: Statistical methods, $6^{\text {th }}$ Ed. Oxford and IBH publishing Co., Calcutta. 